\title{
CITRA DIRJEN BEA DAN CUKAI PADA KASUS PENYELUNDUPAN NARKOBA DALAM TAYANGAN CUSTOMS PROTECTION NET TV
}

\author{
Dwi Desilvani $^{1}$, Hanny Hafiar ${ }^{2}$, Trie Damayanti ${ }^{2}$ \\ ${ }^{1}$ Forest And Climate Change Programme GIZ Indonesia \\ ${ }^{2}$ Universitas Padjadjaran
}

\begin{abstract}
ABSTRAK
Penelitian ini bertujuan untuk mengetahui bagaimana NET TV membingkai kasus penyelundupan narkoba dan membingkai citra Dirjen Bea dan Cukai. Penelitian ini menggunakan teori konstruksi sosial atas realitas Berger dan Luckmann, paradigma konstruktivisme dengan studi analisis framing. Teknik Pengumpulan data: analisis teks, wawancara, observasi partisipan, dan studi pustaka. Teknik analisis data: analisis framing Robert N. Entman dan analisis wawancara. Teknik validitas dan realibilitas data: pengamatan, peningkatan ketekunan, dan triangulasi sumber.

Hasil penelitian ini menunjukkan NET TV membingkai kasus penyelundupan narkoba dengan menampilkan empat pendefinisian masalah, empat perkiraan penyebab masalah, empat keputusan moral, dan empat penekanan penyelesaian masalah. Dengan melakukan penyeleksian isu bersama kesepakatan pihak Dirjen Bea dan Cukai serta melakukan penonjolan isu melalui editing, teks secara lisan maupun tulisan, serta gestur pemain. Citra yang terbingkai pun menjadi dua yaitu citra pelayanan dan perlindungan.

Saran yang dapat diberikan ialah pendefinsian masalah yang timbul dapat menjadi bahan evaluasi Dirjen Bea Cukai; dalam episode rekonstruksi sebaiknya dicantumkan pemberitahuan; sebaiknya NET TV sebagai media massa lebih objektif dan berimbang; penelitian ini hanya terbatas pada aspek teks diharapkan ada penelitian lebih lanjut dengan aspek yang lebih luas.
\end{abstract}

Kata-kata Kunci: Media Massa, Analisis Framing, Citra, Dirjen Bea dan Cukai.

\section{IMAGE OF CUSTOMS AND EXICES IN DRUG SMUGGLING CASE ON CUSTOMS PROTECTION NET TV}

\begin{abstract}
This research aims to determine how NET TV frame the drug smuggling case and frame the Customs and Exices' image. This research is using Social Constructivism on Reality Theory by Berger and Luckmann, constructivism paradigm and framing analysis. Data analysis techniques: text analysis, interview, participant observation, and literature review. Data analysis techniques: framing analysis by Robert $N$. Entman and analytical interview. Data validity and reliability techniques: observation and sources triangulation.

The results of this research indicate NET TV frame with a drug smuggling case featuring four of defining the problem, four approximate cause of the problem, the four moral decisions, and four problem-solving emphasis. By doing the screening issue joint agreement the Director General of Customs and Excise and conduct highlighting the issue through editing, text orally and in writing, as well as gesture's player. framed image becomes two: the image of service and protection. The suggestion can be given is definsian problems that arise can be a material evaluation of the Director General of Customs; the reconstruction of the episode should be appended to the notice; preferably NET TV as mass media is more objective and impartial; This study is confined to the aspects of the text is expected to be further research with a wider aspect.
\end{abstract}

Keywords: Mass Media, Framing Analysis, Image, Customs and Exices

Korespondensi: Dwi Desilvani. Forest And Climate Change Programme GIZ Indonesia. Manggala Wanabakti Building, Block VII, $6^{\text {th }}$ Floor. Jl. Jenderal Gatot Subroto Jakarta.Email: dwi.desilvani@hotmail.com

Submitted: July $1^{\text {st }}, 2016$, Revision: October $1^{\text {st }}, 2016$, Accepted: December $1^{\text {st }}, 2016$

ISSN: 2548-687X (cetak), ISSN: 2549-0087 (online)

http://jurnal.unpad.ac.id/protvf 
PENDAHULUAN

Berpengaruh kuatnya media dalam sebuah perpektif khalayak membuat media berlombalomba menghadirkan program-program yang sesuai dengan ideologinya masing-masing untuk membentuk perspektif pada khalayak yang menerimanya. Hal ini pun terjadi di dalam media di Indonesia yang kini mempunyai latar belakang masing-masing dan mengemas suatu informasi menurut ideologinya. NET Mediatama Televisi adalah stasiun televisi yang baru berdiri 3 tahun dengan menjunjung tinggi ideologinya sebagai "Televisi Masa Kini". NET TV memiliki beberapa program yang berbeda dari program televisi lainnya, terutama reality show yang belum banyak tayang di stasiun televisi di Indonesia.

Sebelumnya, NET TV berhasil mengangkat reality show bertajuk 86 yang melakukan kerjasama dengan Kepolisian Republik Indonesia karena mengangkat banyaknya pelanggaran yang dilakukan di lalu lintas dan perlunya kesadaran publik untuk lebih mematuhi aturan lalu lintas dan sebagainya. Dengan berhasilnya program tersebut, NET TV tidak berhenti pada kasus tersebut saja, mereka melihat maraknya kasus narkoba yang melanda di Indonesia. Hal ini adalah menjadi ancaman eksternal negara yang sangat dapat merusak masyarakat Indonesia. Oleh karena itu, NET TV berkaca dari program televisi "Australian Border" membuat suatu program yang mempertayangkan bagaimana aparat negara kita berusaha mencegah hingga menangani berbagai kasus penyelundupan yang dilakukan dari luar negeri ke dalam negeri yang ditangani oleh Direktorat Jenderal Bea dan Cukai.

Sadar kurangnya pengetahuan khalayak terhadap peraturan yang berlaku untuk peredaran barang-barang impor maupun ekspor di sini lah peran media untuk memberikan informasi dan memberikan tayangan berkualitas agar publik lebih sadar dan menaati peraturan tersebut, tercetuslah program "Customs Protection". Program Customs Protection ini diusulkan pada tahun 2014 dan mengajukan permohonan kerjasama dari NET TV kepada Direktorat Jenderal Bea dan diterima pada awal tahun 2015.

"Customs Protection ini bermuatan news tapi dikemas dengan real atau reality show oleh karena itu program ini masuk dalam kategori produksi bukan news walaupun muatan informasinya adalah news. Tidak ada rekayasa dalam tayangan ini, hanya saja kami melakukan rekonstruksi jika terdapat kasus yang menarik untuk diliput tetapi kami tidak ada di tempat dan masih terdapat barang bukti yang dapat dipergunakan untuk rekonstruksi. Untuk rekonstruksi pun kami memilih kasus mana yang sekiranya menarik untuk ditayangkan atau tidak."1

Customs Protection ini menyasar publik terutama yang sering melakukan perjalanan ke luar negeri serta publik yang sering melakukan barang ekspor dan impor, agar lebih mengetahui regulasi yang berlaku di Indonesia. Program ini tayang pada akhir pekan yaitu hari Sabtu dan Minggu pukul 22.00. Publik yang disasar antara lain dewasa dengan rentang umur 35 tahun sampai 39 tahun dengan bergender laki-laki. Pada segmentasi tersebut menyukai tayangan yang logis dan cenderung menarik atau seru. Akan tetapi tentu saja NET TV tetap melakukan pembingkaian dalam setiap episodenya dikarenakan latar belakangnya yang menjalin kerjasama dengan Dirjen Bea Cukai.

Terdapat beberapa terlihat NET TV ingin menyampaikan informasi bahwa program ini adalah program kerjasama dengan Dirjen Bea Cukai. Dengan adanya lambang Dirjen Bea dan Cukai dalam pembukaan "Customs Protection" ini dengan dituliskan "Bekerjasama Dengan Direktorat Jenderal Bea Dan Cukai Hubungan Masyarakat" hal tersebut telah memberikan citra tesendiri bagi yang menyaksikan tayangan ini terhadap Dirjen Bea dan Cukai, serta petugas

\footnotetext{
${ }^{1}$ Hasil Wawancara dengan Achmad Ali Ghufron selaku Kreatif Customs Protection NET TV Pada 10 Januari 2016
} 
yang memakai seragam bertuliskan "Bea Dan Cukai" dengan gagahnya, petugas mengenakan seragamnya memperlihatkan ketegasannya dan kepaiawaiannya dalam melaksanakan tugas serta tulisan yang memperilihatkan bahwa tayangan ini murni documenter terdapat katakata sebelum pembukaan acara ini yaitu "Semua Kejadian Dalam Tayangan Ini Tanpa Rekayasa". Dengan adanya kerjasama yang terjalin, NET TV melakukan pembingkaian yang menimbulkan citra dan reputasi tersendiri bagi penonton. Seperti yang dikatakan Kurt Lang dan Gladys Engel Lang bahwa

"Media massa memaksakan perhatian pada isu-isu tertentu. Media massa membangun citra publik tentang figur-figur politik. Media massa secara konstan menujukkan apa yang hendak dipertimbangkan diketahui dan didasarkan individu-individu masyarakat" ${ }^{2}$

Di sini lah NET TV mengonstruksi informasi yang mereka dapatkan dan menampilkannya kepada masyarakat dengan ideologi yang mereka anut. Dengan adanya konstruksi atas realitas yang dilakukan NET TV, hal tersebut dapat menimbulkan citra tersendiri kepada instansi Dirjen Bea Cukai. NET TV melakukan penyeleksian dan penonjolan isu yang menurut NET TV penting dan layak untuk diperlihatkan kepada publik. Begitu pun hal yang tidak penting dan menurut NET TV dapat menurunkan nama baik Dirjen Bea Cukai akan dihapuskan atau tidak ditayangkan oleh tim NET TV. ${ }^{3}$

Di sini lah peran media untuk memberikan informasi yang akurat, tanpa rekayasa, dan menarik untuk dilihat. Informasi yang diberikan oleh NET TV dalam program "Customs Protection" ini memberikan pembingkaian tersendiri dikarenakan NET TV melakukan kerjasama dengan Direktorat Jenderal Bea dan Cukai. Bagaimana NET TV dapat menghadirkan informasi mengenai kepabeanan dan kasus-kasus yang melibatkan Direktorat

\footnotetext{
${ }^{2}$ Tambura, Apriadi “Agenda Setting Media Massa”, 2012
}

Jenderal Bea dan Cukai dengan menjunjung ideologi stasiun televisinya. Bagaimana NET TV melakukan menyeleksian isu yang dihadirkan serta dipertontonkan kepada permisa dengan melewati review terlebih dahulu kepada pejabat Direktorat Jenderal Bea dan Cukai. NET TV juga melakukan penekanan-penekanan untuk membuat tayangan menjadi lebih menarik dan memberikan penekanan terhadap suatu isu yang ingin ditonjolkan oleh NET TV agar publik mengikuti perpektif NET TV dalam melihat suatu kasus yang melibatkan Direktorat Jenderal Bea dan Cukai ini.

Hubungan penelitian ini dengan ilmu hubungan masyarakat adalah pentinganya peran media terhadap citra suatu institusi atau lembaga. Bagaimana sebuah media dapat melihat suatu isu yang berkaitan dengan lembaga tersebut dan menghadirkannya kepada publik yang dapat memberikan citra tersendiri terhadap lembaga tersebut. Oleh karena itu, peneliti ingin mengetahui bagaimana citra Direktorat Jenderal Bea dan Cukai dalam tayangan Customs Protection khususnya dalam kasus penyelundupan narkoba.

\section{TINJAUAN PUSTAKA}

Pengertian komunikasi massa telah banyak dikemukakan para ahli di bidang sosial dan komunikasi. Pengertian komunikasi yang paling sederhana adalah dari Bittner, yakni :

"Mass Communiaction is a messages communicated through a mass mediaum to a large number of people, (Komunikasi massa adalah pesan yang dikomunikasikan melalui media massa pada sejumlah besar orang)" (Elvinaro dkk, 2007:3)

Pengertian lain yang lebih terperinci dikemukakan ahli komunikasi lain, yaitu Gerbner. Menurut Gerbner, pengertian komunikasi massa adalah sebagai berikut:

"Mass communication is the technologically and instituationally

\footnotetext{
${ }^{3}$ Hasil Wawancara dengan Yudhistira Utama selaku Production Assistan Customs Protection NET TV Pada 29 September 2016
} 
based production and distrubution of the most broadly shared contionous flow of messages in industrial societies." (Komunikasi massa adalah produksi dan distribusi yang berlandaskan teknologi dan lembaga dari arus pesan yang kontinyu serta paling luas dimiliki orang dalam masyarakat industri) (Elvinari dkk, 2007:3)

Ahli komunikais lainnya, Joseph A. DeVito mengemukakan definisinya mengenai komunikasi massa dalam dua item, yakni :

"Pertama, komunikasi massa adalah komunikasi yang ditujukan kepada massa, kepada khalayak yang luar biasa banyaknya. Kedua, komunikasi massa adalag komunikasi yang disalurkan oleh pemancar-pemancar yang audio dan/atau visual." (Elvinaro dkk, 2007: 56).

Dari berbagai definisi yang dikemukakan para hali tersebut, antara satu definisi dengan definisi yang lain tidak ada pertentangan dan bahkan saling melengkapi satu sama lain. Dari pengertian tersebut pula bisa diketahui karakteristik dari komunikasi massa yang mebedakannya dengan jenis-jenis komunikasi lainnya. Dari berbagai definisi komunikais massa yang telah dikemukkan parah ahli sebelumnya, Rakhmat merangkumnya sebagai berikut:

"Komunikasi massa diartikan sebagai jenis komunikasi yang ditujukan kepada sejumlah khalayak yang tersebar, heterogen, dan anonym melalui media cetak atau elektronik sehingga pesan yang sama dapat diterima secara serentak dan sesaat." (Elvinaro dkk, 2007:6).

Teori konstruksi sosial atas realitas yang dikemukakan Berger dan Luckman tidak memasukkan media massa sebagai veriable atau fenomena yang berpengaruh dalam konstruksi sosial atas realitas. Sebagai seorang sosialog dan ahli di bidang media massa, Burhan Bungin mengungkapkan pandangannya mengenai konstruksi sosial yang di dalamnya di masukkan media massa sebagai varibelnya sebagai berikut:
Posisi "konstruksi sosial media massa" adalah mengoreksi substansi kelemahan dan melengkapi "konstruksi sosial atas realitas", dengan menempatkan seluruh kelebihan media massa dan efek media pada keunggulan "konstruksi sosial media massa" atas "konstruksi sosial atas realitas". Bungin menjelaskan, konstruksi sosial dalam media massa tidak muncul begitu saja. Ia memaparkan, proses kelahiran kosntruksi sosial media massa lahir melalui tahap-tahap sebagai berikut: (a) tahap menyiapkan materi konstruksi; (b) tahap sebaran konstruksi; (c) tahap pembentukan konstruksi realitas; dan (d) tahap konfirmasi (Bungin, 2008:195).

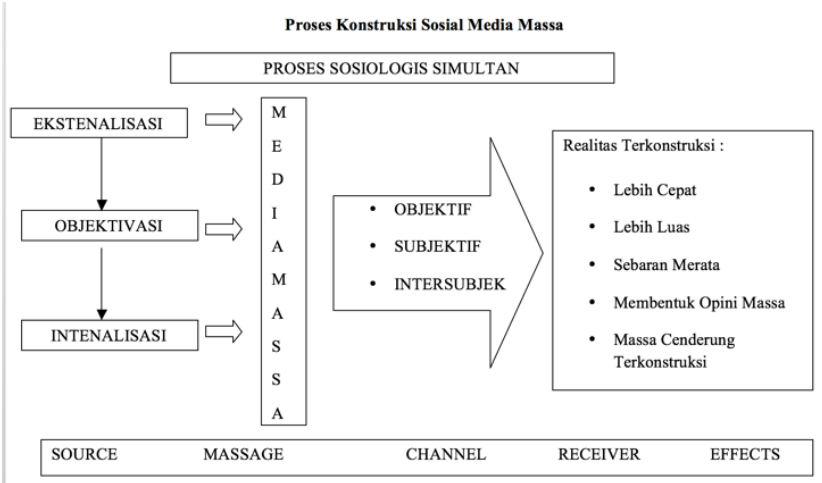

Gambar 1. Konstruksi Media Massa

(Sumber: Bungin, 2008:195)

Menyiapkan materi konstruksi sosial media massa adalah tugas redaksi media massa. Masing-masing media memilki sistem keredaksian yang berbeda-beda sesuai dengan kebutuhan dan visi suatu media. Ada tiga hal penting dalam proses penyiapan materi konstruksi sosial, yaitu keberpihakan media massa kepada kapitalisme, keberpihakan semua kepada masyarakat, serta keberpihakan kepada kepentingan umum. Jadi, dalam menyiapkan materi konstruksi, media massa memosisikan diri pada tiga hal tersebut (Bungin, 2008: 195197). Namun, pada umumnya keberpihakan kepada kepentingan kapitalis menjadi sangat dominar mengingat media massa adalah mesi produksi kapitalis yang mau ataupun tidak harus menghasilkan keuntungan. Tidak jarang dalam menyiapkan sebuah materi pemberitaan, terjadi 
pertukaran kepentingan di antara pihak-pihak yang berkepentingan.

Tahap berikut setelah sebarab konstruksi adlaah tahap pembentukan konstruksi realitas, dimana pemberitaan telah sampai pada pembaca dan pemirsanya sehingga terjadi pembentukan konstruksi di masyarakat yang berlangsung dalam tiga tahap. Pertama, konstruksi realitas pembenara; kedua, kesediaan dikonstruksi oleh media massa; ketiga, sebagai pilihan konsumtif.

Tahap pertama konstruksi pembenaran sebagai salah satu bentuk konstruksi media massa yang terbangun di masyarakat yang cenderung membenarkan apa saj ayang ada (tersaji) di media massa sebagai sebuah realitas kebenaran. Dengan kata lain, informasi media massa sebagai otoritas sikap untuk membenarkan sebuah kejadian. Ini adalah pembentukan konstruksi tahap pertama.

Tahap kedua adalah kesediaan dikonstruksi oleh media massa, yaitu sikap generik dari tahap yang pertama. Bahwa pilihan seseorang untuk menjadi pembaca dan pemirsa media massa adalah karena pilihannya untuk bersedia pikiran-pikirannya dikonstruksi oleh media massa.

Tahap ketiga adalah menjadikan konsumsi media massa sebagai pilihan konsumtif, di mana seseorang secara habit (kebiasaan) tergantung pada media massa. Media massa adalah bagian kebiasaan hidup yang tak bisa dilepaskan. Tanpa hari tanpa menonton televisi, tanpa hari tanpa membaca koran, tanpa hari tanpa mendengar radio, dan sebagainya. Pada tingkat tertentu, seseirang merasa tak mampu beraktivitas apabila ia belum membaca koran atau menonton televisi pada hari itu (Bungin, 2008: 198-199).

\section{Agenda Setting Model}

Agenda Setting Model menyatakan media massa, dengan memperhatikan beberapa isu tertentu dan mengabaikan yang lainnya, akan memengaruhi opini publik. Orang cenderung mengetahui tentang hal-hal yang disajikan oleh madia massa dan menerima susunan prioriyas yang ditetapkan media massa terhadap berbagai berbagai isu tersebut. Asumsi ini menyangkut pemahaman (learning), bukan perubahan sikap perubahan opini. Studi empiris tentang komunikasi massa pada hakikatnya tekah mengonfirmasi bahwa efek yang paling memungkinakan terjadi akan berkaitan dengan masalah materi informasi. Asumsi agenda setting menawarkan suatu cara menghubungkan penemuan-penemuan tersebut dengan kemungkinan-kemungkinan efek terhadap opini (Elvinaro Ardinato, dkk, 2007)

Asumsi dasar Agenda Setting Model (model penataan agenda) menurut Cohen ini adalah "The press is significanly more than a surveyor of information and opinion. It may not be sucessful much of the time in telling the people what to think, but it is stunningly successful in telling readers what to think about". Antara berbagai topik yang dimuat di media massa, topik yang lebih banyak mendapat perhatian dari media massa akan menjadi lebih pagi pembacanya. (Elvinaro Ardianto, dkk, 2007).

\section{HASIL DAN PEMBAHASAN}

Tabel 1. Ringkasan Framing Customs Protection Episode Penyelundupan Narkoba

\begin{tabular}{|c|c|c|c|c|c|}
\hline \multirow[t]{2}{*}{ No } & \multicolumn{4}{|c|}{ Elemen Analisis Framing Robert N. Entman } & \multirow[t]{2}{*}{ Bukti Episode } \\
\hline & $\begin{array}{c}\text { Pendefinisian } \\
\text { Masalah }\end{array}$ & $\begin{array}{c}\text { Perkiraan } \\
\text { Penyebab Masalah }\end{array}$ & Keputusan Moral & \begin{tabular}{|c|} 
Penekanan \\
Penyelesaian Masalah \\
\end{tabular} & \\
\hline 1. & $\begin{array}{l}\text { Kurangnya data } \\
\text { informasi } \\
\text { penyergapan }\end{array}$ & $\begin{array}{l}\text { Intelejen / Lembaga } \\
\text { terkait (Mabes Polri) }\end{array}$ & \begin{tabular}{|l|} 
Kurangnya \\
perencanaan \\
matang dari \\
divisi/instansi \\
terkait
\end{tabular} & $\begin{array}{l}\text { Melakukan pengecekan } \\
\text { lebih mendalam }\end{array}$ & \begin{tabular}{|l|} 
"Detik-Detik Pengejaran \\
Tersangka Penyelundup \\
Sabu-Sabu" \\
"Penelusuran Pengiriman \\
Narkoba di Bandara \\
Soekarno-Hatta" \\
\end{tabular} \\
\hline 2. & $\begin{array}{l}\text { Kebocoran } \\
\text { informasi }\end{array}$ & $\begin{array}{l}\begin{array}{l}\text { Kecerobohan } \\
\text { petugas }\end{array} \\
\end{array}$ & \begin{tabular}{|l|} 
Petugas tidak \\
mampu menyimpan \\
informasi
\end{tabular} & \begin{tabular}{|l|} 
Menunggu \& \\
berkoordinasi dengan \\
pihak yang terkait \\
(maskapai)
\end{tabular} & $\begin{array}{l}\text { "Penelusuran Pengiriman } \\
\text { Narkoba di Bandara } \\
\text { Soekarno-Hatta" }\end{array}$ \\
\hline 3. & $\begin{array}{l}\text { Sulit } \\
\text { berkomunikasi }\end{array}$ & $\begin{array}{l}\text { Petugas yang belum } \\
\text { menguasai bahasa } \\
\text { asing }\end{array}$ & \begin{tabular}{|l|} 
Dirjen Bea Cukai \\
yang masih kurang \\
dalam \\
pengembangan \\
SDM \\
\end{tabular} & Memanggil translator & \begin{tabular}{|l|} 
"Detik-Detik Pengejaran \\
Pelaku Penyelundup Sabu" \\
"Kiriman Tim Paket Sabu"
\end{tabular} \\
\hline 4. & Modus baru & Pelaku yang lihai & \begin{tabular}{|l|} 
Tidak bermoral, \\
kesengajaan pelaku
\end{tabular} & $\begin{array}{l}\text { Melakukan atensi lebih } \\
\text { terhadap barang yang } \\
\text { masuk }\end{array}$ & \begin{tabular}{|l} 
"Penelusuran Peredaran Sabu \\
Cair" \\
"Penangkapan Bandar Sabu \\
di Bandara" \\
"Detik-Detik Pengejaran \\
Pelaku Sabu"
\end{tabular} \\
\hline
\end{tabular}

Analisis framing dalam konsepsi Robert N. Entman yang merujuk pada pemberian definisi, penjelasan, evaluasi, dan rekomendasi ini menekankan kerangka pemikiran Customs Protection NET TV. Program ini memandang bahwa permasalahan penyelundupan nanrkoba ini adalah persoalan yang akan mengancam bangsa Indonesia terutama generasi muda yang 
menjadi sasaran utama pelaku penyebaran narkoba. Kasus ini adalah kasus penting yang dipandang NET TV untuk diangkat karena peristiwa narkoba ini adalah termasuk kasus kejahatan luar biasa dan harus diberantas.

"Kriminal pastinya, karena penyelundupan narkoba sudah menjadi kejahatan yang paling sadis, karena kalau sabu itu sampai jatuh ke Indonesia terus diperdagangkan lalu yang memakai adalah salah satu dari keluarga kita dijamin kita pasti sedih, oleh karena itu, hal tersebut kejahatan luar biasa"

Menurut Apriandi Tamburaka dalam bukunya Agenda Setting Media Massa yang menyatakan bahwa terdapat dua asumsi dasar yang paling medasari tentang penentiuan agenda diantaranya: yang pertama, masyarakat pers dan media massa tidak mencerminkan kenyataan dan mereka menyaring dan membentuk isu, dan yang kedua, konsentrasi media massa hanya pada beberapa masalah masyarakat untuk ditayangkan sebagai isu-isu yang lebih penting daripada isu-isu lain. Oleh karena itu, NET TV tertarik mengangkat isu penyelundupan narkoba ini karena menurut mereka isu ini isu penting dan menarik dalam tayangan. Dalam kenyataannya, tidak dipungkiri stasiun televisi ini mengejar rating untuk mendapatkan keuntungan bagi medianya maupun karyawan di dalamnya. Menurut salah satu crew Customs Protection, isu penyelundupan narkoba ini adalah salah satu isu yang dapat mendorak rating Customs Protection oleh karena itu tim sangat mengutamakan isu ini. ${ }^{5}$

Pada pembingakian kasus penyelundupan narkoba yang dilakukan NET TV pada program Customs Protection ini diperlihatkan dengan mengangkat empat pendefinisian masalah sebagai masalah yang penting bagi Bea Cukai diantaranya kurangnya informasi penyergapan, kebocoran informasi,

\footnotetext{
${ }^{4}$ Hasil Wawancara dengan Wildan Kesuma Putra selaku Production Assitant Customs Protection NET TV Pada 23 September 2016
} sulit berkomunikasi dan modus baru. NET TV juga menentukan empat penyebab masalah yang dapat datang dari internal maupun eksternal Bea Cukai, menetapkan empat keputusan moral yang mengangkat bahwa Bea Cukai masih harus melakukan pembenahan, serta empat penekanan masalah yang memperlihatkan bahwa Bea Cukai selalu dapat menyelesaikan masalahnya dan menangkap pelaku penyelundupna narkoba. Dalam unsur pembingkaian ini, Robert N. Entman juga melihat secara luas unsur analisis framing ini yaitu: penyeleksian isu dan penonjolan atau penekanna aspek. Dalam melakukan penyeleksian isu NET TV sebagai media dapat menggiring opini publik mengenai persepsi publik terhadap Bea Cukai melalui penyeleksian isu. NET TV juga melakukan penekanan isu untuk mendukung penggiringan opini publik terhadap persepsi penonton mengenai Bea Cukai. Berikut ini adalah pemaparan kerangka pikir Customs Protection NET TV dari konsepsi Robert N. Entman.

Pemberitaan mengenai permasalahan terkait penyelundupan narkoba yang diangkat oleh Customs Protection NET TV sebagai materi khusus yang dihadirkan di setiap episode yang muncul. Dalam episode tersbeut menceritakan bagaimana begitu banyaknya modus yang dilakukan pelaku untuk menyelundupkan narkoba dan menyebarkannya di Indonesia. Hal tersebut menjadi masalah penting bagi Dirjen Bea dan Cukai karena masih banyak masalah yang timbul dari internal Bea Cukai dan menyebabkan selalu ada saja oknum yang berani menyelundupkan narkoba ke Indonesia. NET TV menayangkan beberapa permasalahan yang timbul dalam tayangan penyelundupa narkoba salah satunya adalah masalah kurangnya data informasi penyergapan. Masalah kurangnya data informasi penyergapan ini menetapkan

\footnotetext{
${ }^{5}$ Hasil Wawancara dengan Yudhistira Utama selaku Production Assitant Customs Protection NET TV Pada 23 September 2016
} 
perkiraan penyebab masalah sebagai aktor dalam masalah ini adalah pihak intelejen mauapun mabes polri yang terlibat dalam menyediakan data informasi. Dalam masalah ini NET TV juga membuat suatu keputusan moral yaitu kurangnya perencanaan matang dari divisi intelejen maupun mabes polri.

Pendefinisian masalah ini adalah salah satu unsur analisis framing Robert N. Entman yang dapat menjadi master frame pertama yang dilakukan media dalam memandang sebuah informasi. Pendefinsian masalah adalah elemen pertama kali dapat kita lihat mengenai framing. Elemen ini merupakan master frame atau bingkai paling utama. Robert N. Entman dalam buku Eriyanto, Analisis Framing, menekankan bagaiamna peritiwa dapat dipahami oleh wartawan. Maka di sini lah, NET TV bagaimana memandang permasalahan yang terjadi dalam kasus penyelundupan narkoba yang menjadi masalah pula bagi petugas Bea Cukai.

Pada pendefinisian masalah kedua yaitu kebocoran informasi ini diperlihatkan pada episode "Penelusuran Pengiriman Narkoba di Bandara Soekarno-Hatta". Pendefinisian masalah yang dilakukan oleh NET TV pada episode ini adalah saat mengatakan idak ada cargo sama sekali dalam pengiriman hari itu. Kami menduga informasi kami sudah bocor." Teks tersebut terucap pada menit 6:34. NET TV membingkai permasalahan ini pula karena permasalahan ini dianggap menarik untuk diangkat karena kembali menimbulkan polemik dan opini publik bahwa informasi Bea Cukai pun bahkan dapat bocor.

Menurut Eriyanto, Framing meringkas realitas yang kompleks penuh dimenasi, dan tidak beraturan menjadi tersaji dalam berita sebagai sesuatu yang sederhana,beraturan dan memenuhi logika tertentu. NET TV terutama program Customs Protection meringkas kasus ini sebagai permasalahan kriminal atau kejahatan yang luar biasa dan dapat merusak moral bangsa. Akan tetapi, di sini terlihat, terutama pada episode on the spot atau langsung dan tidak melakukan rekonstruksi, NET TV sering kali merekam berbagai masalah yang timbul dari internal Bea Cukai dan menurut NET TV menarik untuk ditampilkan. Hal tersebut menjadi suatu definisi masalah yang dipilih oleh NET TV dalam beberapa episode penyelundupan narkoba.

Pada instansi yang diberikan tugas menjaga perbatasan negara, seharusnya menjadi sebuah kewajiban dalam menguasai bahasa asing, dikarenakan sudah menjadi tugas sehari-harinya dalam menangani orang asing. Akan tetapi, masalah sulit berkomunikasi ini masih muncul pada petugas Dirjen Bea Cukai dan ditayangkan pada program Customs Protection dalam episode "Kiriman Tim Paket Sabu" dan "DetikDetik Pengejaran Tersangka Penyelundup Sabu". Pendefinisian masalah ini ditekankan dengan adegan dan testimoni narasumber. Pada adegan tersebut jelas ditekankan oleh narasumber dalam testimoninya bahwa mereka memiliki masalah pada bahasa dan tidak dapat mengerti apa yang dikatakan oleh pelaku, petugas pun harus memanggil translator untuk mengetahui apa yang sedang dibicarakan pelaku.

Dalam pendefinisian masalah ini, NET TV memperkirakan penyebab masalahnya adalah Dirjen Bea Cukai secara internal karena belum maksimal dalam pengembangan Sumber Daya Manusianya yang di sini adalah petugas Bea Cukai. Hal tersebut diakui oleh Yudhistira Utama selaku Production Assitant Customs Protection.

"Mulai ke sini mulai dicari yang dapat berbahasa asing karena permasalahan awal di program ini adalah banyak masyarakat atau penonton mengeluh dan dari Bea Cukai sendiri mengakui banyak petugas bandara yang kurang fasih berbahsa asing, Inggris, Mandarin, Korea, Jepang paling tidak bahasa Inggris" 6

\footnotetext{
${ }^{6}$ Hasil Wawancara dengan Yudhistira Utama selaku Production Assitant Customs Protection NET TV Pada 23 September 2016
} 
NET TV menganggap bahwa masih banyak keluhan penonton yang mengamini petugas yang masih berkesulitan dalam penguasaan bahasa asing. Hal tersebut menyebabkan masalah sulitnya berkomunikasi yang masih dapat dilihat di pendefinisian masalah dalam episode penyelundupan narkoba sekalipun. Akan tetapi, kembali NET TV menampilkan permasalahan ini sesuai dengan yang dikatakan Wildan Kesuma Putera selaku Production Assistant bahwa masalah ini juga menarik untuk diangkat. Masalah sulit berkomunikasi ini menjadi masalah yang dapat membuat Dirjen Bea Cukai lebih berkaca dan melakukan evaluasi atas SDMnya yang masih kurang dalam penguasaan bahasa asing

"Sebenarnya kalau untuk sulit berkomunikasi kita munculkan karena itu memang menjadi hambatan bagi petugas Bea Cukai sampai saat ini hal itu kami munculkan untuk mejadikan evaluasi juga buat mereka bahwa menguasai bahasa asing selain bahasa inggris itu penting untuk petugasnya tidak hanya dalam penindakan di kepabeanan dan cukai saja tetapi juga untuk pelaku penyelundup narkoba yang berasal dari beberapa negara."7

Diagnose Causes atau memperkirakan penyebab masalah menurut Entman, merupakan elemen framing untuk membingkai siapa yang dianggap sebagai aktor dari suatu peristiwa. Penyebab di sini dapat berarti apa tetapi juga bisa siapa. Bagaimana peristiwa dipahami oleh tim NET TV, dan tentu saja menentukan apa dan siapa yang dianggap sebagai sumber masalah. Di sini lah sebenarnya NET TV menetapkan aktor di balik pendefinisian masalah ini adalah internal Dirjen Bea Cukai sendiri yang belum mampu mengembangkan SDMnya. Akan tetapi, penyebab masalah ini hanya tersirat dalam adegan tersebut tidak terlalu ditekankan karena kembali NET TV memiliki kerjasama dengan Dirjen Bea Cukai.
Penyebab masalah yang ditampilkan oleh NET TV terlihat bersamaan dengan testimoni pendefinisian masalahnya. Dimana narasumber berkata bahwa petugas mengalami masalah dalam bahasa dan harus memanggil translator di situ lah NET TV memperlihatkan bahwa hal tersebut disebabkan petugas yang tidak mampu menguasai bahasa selain bahasa inggris dan menyebabkan sulit berkomunikasi.

Pada akhirnya, NET TV membingkai dengan menekankan penyelesaian masalahnya dengan memanggil translator dari luar, dan menyebabkan permasalahn kemudia selesai dan petugas mampu memperoleh keterangan dari pelaku. Bagi kaum konstrukstivisme, realitas (berita) itu hadir dalam keadaan subjektif. Realitas tercipta lewat konstruksi, sudut pandang dan ideologi wartawan. Bagaimana sudut pandang media dalam melakukan framing suatu informasi dapat terlihat dari bagaimana media menekankan penyelesaian dan memberikan rekomendasi. Treatment recomendetion dipakai untuk menilai apa yang dikehendaki oleh wartawan. Jalan apa yang dipilih untuk menyelesaikan masalah.

Pemberitaan mengenai permasalahan terkait penyelundupan narkoba yang diangkat oleh Customs Protection NET TV sebagai materi khusus yang dihadirkan di setiap episode yang muncul. Dalam episode tersbeut menceritakan bagaimana begitu banyaknya modus yang dilakukan pelaku untuk menyelundupkan narkoba dan menyebarkannya di Indonesia. Hal tersebut menjadi masalah penting bagi Dirjen Bea dan Cukai karena masih banyak masalah yang timbul dari internal Bea Cukai dan menyebabkan selalu ada saja oknum yang berani menyelundupkan narkoba ke Indonesia. Teori Penentuan Agenda atau Agenda Setting Theory adalah teori yang menyatakan bahwa media massa berlaku merupakan pusat penentuan kebenaran dengan kemampuan

\footnotetext{
${ }^{7}$ Hasil Wawancara dengan Wildan Kesuma Putra selaku Production Assitant Customs Protection NET TV Pada 23 September 2016
} 
media massa untuk mentransfer dua elemen yaitu kesaran informasi ke dalam agenda publik yang mengarahkan kesadarn publik serta perhatiannya kepada isu-isu yang dianggap penting oleh media massa.

Walter Lipmann pernah mengutarakan pula pernyataan bahwa media berperan sebagai mediator. Terdapat korelasi yang kuat dan signifikan antara apa-apa yang diagendakan oleh media massa dan apa yang menjadi agenda publik. Di sini NET TV memilih pendefinisian masalah modus baru sebagai salah satu isu yang penting dari isu-isu lainnya. Dimana isu ini sinergi dengan program Presiden yang ingin memberantas narkoba dengan Operasi Bersinar (Berantas Sindikat Narkoba). Masalah modus baru ini selalu menjadi masalah yang begitu mengancam bagi pihak Bea Cukai yang datang dari pihak eksternal yaitu pelaku penyelundupan narkoba. Masalah modus baru juga dianggap materi yang menarik untuk diangkat karena keberagaman modus yang dihadirkan oleh pelaku. Kembali tidak memungkiri NET TV mengejar rating saat penayangan modus baru ini biasanya mendapatkan rating tinggi.

"Masalah modus baru ini penting ditayangkan karena menyangkut kelihaian pelaku untuk menyelundupkan narkoba dan modus yang digunakan pun kandangkadang aneh-aneh seperti ada yang di anus, pembalut wanita lah, atau di belakang kerudung lah. Hal tersebut lah yang membuat episode modus baru menjadi selalu menarik untuk kami tayangkan di beberapa episode Customs."

Pendefinisian modus baru ini dalam episode penyeludunpan narkoba sering kali diberikan penekanan dari judul episode saja. Bahkan, dalam running text sebelum acara tayang sudah ditayangkan untuk membuat penonton tertarik menonton episode tersebut. Pendefinisian masalah modus baru ini biasa ditekankan mulai dari judul episode seperti
"Penelusuran Peredaran Sabu-Sabu Cair" atau "Seorang Pria Kedapatan Membawa Nakoba di Lipatan Baju" bahkan judul seperti "Seorang Wanita Diperiksa Kedapatan Membawa Barang Di Dalam Pembalut". Judul-judul ini yang dapat menjadi headline dalam tayangan Customs Protection untuk menarik penonton melihat tayangan Customs Protection. Tidak hanya melalui judul episode yang memberikan penekanan pada masalah modus baru, dalam berbentuk teks testimonial juga biasa dilakukan oleh tim Customs Protection.

Dalam teks pendefinisian modus baru ini dilakukan pembingkaian oleh NET TV dengan melakukan penegasan di dalam teks yang muncul. Dalam penegasan ini, pembingkaian berisikan perspektif yang digunakan si penulis ketika mengonstruksi fakta atau fenomena sebagai dasar penonjolan gagasan ini tulisannya. Seperti pada episode "Penelusuran Peredaran Sabu-Sabu Cair", NET TV menekankan permasalahan modus baru ini dengan narasumbernya yang berkata,

"Ini adalah modus baru dimana sebelumnya belum pernah terjadi. Mereka dengan sangat lihai menyamarkan sabu-sabu menjadi sabu berbentuk semacam lem. Barang dan pengemasnya sejumlah $65 \mathrm{Kg}$ tapi untuk isinya sendiri sekitar ada $53 \mathrm{Kg}$. Jumlah yang cukup besar untuk narkoba jenis sabu-sabu ini dan terbesar yang pernah ditemukan di kantor kami ini." (Menit $1: 52)$

Dengan menggunakan efek suara transisi untuk menekankan bahwa modus ini adalah modus baru, NET TV berusaha memberikan penekanan menggunakan efek suara pada transisi. Suara, sebagai tanda terjalin sangat erat dengan yang dimaksud pada gambar. Suara bersama gambarnya memang ikonis, tetapi kekuatan keberadaanya pada akhirnya diperoleh dari indeksikalitas. Karena realitas yang ditampilka, seluruhnya atau sebagian,

\footnotetext{
${ }^{8}$ Hasil Wawancara dengan Wildan Kesuma Putra selaku Production Assitant Customs Protection NET TV Pada 23 September 2016
} 
tidak hanya mirip, tetapi juga memiliki keterkaitan dengan realitas kita. Semakin besar keterkaitan tersebut, maka semakin dapat muncul pula identifikasi dan adegan pun akan semakin dapat 'menyentuh' kita. ${ }^{9}$

Public Relations dan media adalah dua hal yang tidak dapat dipisahkan terutama bagi instansi Direktorat Jenderal Bea dan Cukai. Dengan sejumlah berita miring mengenai instansinya, bagian Hubungan Masyarakat Dirjen Bea Cukai membangun mitra yang baik dengan media untuk menjangkau stakeholder utama Dirjen Bea Cukai yaitu masyarakat. Kendati dengan pesatnya pertumbungan dunia media, terlebih media online, Dirjen Bea Cukai merasa kerjasama dengan media begitu penting untuk meningkatkan citra serta memberikan informasi tentang kegiatan serta kebijakan Bea Cukai yang belum banyak masyarakat ketahui. Menurut Siswanto Sutojo, citra sebagai pancaran atau reproduksi jati diri atau bentuk orang perseorangan, benda, atau organisasi. Citra sebagai persepsi masyarakat terhadap jati diri perusahaan atau organisasi. Mengetahui citra merupakan salah satu evaluasi stakeholder terhadap organisasi atau instansi sepanjang waktu yang didasarkan atas pengalaman stakeholder tersebut dengan organisasi.

Media massa, melalui pada timnya merupakan stakeholder yang berhubungan langsung dengan Dirjen Bea Cukai, mereka menjadi consumer atas informasi-informasi mengenai berbagai kasus yang melibatkan Dirjen Bea Cukai itu sendiri. Oleh karena itu, Dirjen Bea Cukai begitu memanfaatkan kerjasama yang dilakukan antara NET TV dengan Dirjen Bea Cukai melalui tayangan Customs Protection. Menurut Devid Yohannes Muhammad selaku Kasie Hubungan Masyarakat Dirjen Bea Cukai, pihak Bea Cukai mendapatkan berbagai manfaat dari adanya program ini yang menjadikan program ini

\footnotetext{
${ }^{9}$ Sobur, Alex. Semiotika Komunikasi.2010
}

strategi untuk berkomunikasi dengan masyarakat secara luas.

"Customs Protection oleh NET TV ini banyak yang kita peroleh baik dari strategi Bea Cukai ke depanya seperti apa, dan masyarakat juga untuk saat ini informasi mengenai Bea Cukai kan masih terbatas untuk masyarakat yang diterima. Apasih yang dilakukan Bea Cukai? Nah setelah ada NET TV, dia masuk dalam program yang sifatnya dapat menjaring permisa yang banyak, hal itu menjadi salah satu startegi Bea Cukai untuk menjangkau masyarakat. Karena keterbatasan yang kita miliki, ya dengan adanya pihak dari media elektronik, buat saya sih hal ini membuat kita dengan mudah dikenal dengan masyarakat"10

Dengan adanya kerjasama yang dilakukan NET TV bersama Dirjen Bea Cukai hal ini membuat NET TV memiliki prespektif yang terbingkai di dalam tayangan Customs Protection ini. Customs Protection ini adalah salah satu program reality show dengan bermuatan berita di dalamnya. Dalam berita yang disampaikan di dalamnya terdapat konstruksi atas realitas yang ditampilkan. Dengan adanya kerjasama antara NET TV dengan Dirjen Bea Cukai, membuat NET TV mempunyai kebijakan tersendiri dalam melakukan pengemasan informasi yang dimuat dalam program Customs Protection. Menjaga 'nama baik' Dirjen Bea Cukai menjadi kebijakan yang utama bagi tim Customs Protection dalam mengemas informasi yang akan tayang kepada penonton. Analisis framing kemudian dilakukan untuk mengetahui bagaimana NET TV mengkonstruksi informasi mengenai Dirjen Bea Cukai.

Konsep framing oleh Robert N. Entman digunakan untuk menggambarkan proses

\footnotetext{
${ }^{10}$ Hasil Wawancara dengan Devid Yohannes Muhammad selaku Kasie Hubungan Masyarakat Dirjen Bea dan Cukai Kementerian Keuangan RI Pada 9 September 2016
} 
seleksi dan menonjolkan aspek tertentu dari realitas oleh media. Entman melihat framing dalam dimensi besar: seleksi isu dan penekana atau penonjolan aspek-aspek tertentu. Salah satu strategi untuk menonjolkan aspek isu tertentu yaitu menempatkan pemberitaan penangkapan penyelundupan narkoba ini menjadi informasi utama Customs Protection pada setiap minggunya. Dalam pengemasan informasi yang terdapat dalam Customs Protection ini, NET TV melakukan penyeleksian isu dan penonjolan aspek di dalam setiap episode penyelundupan narkoba. Penyeleksian isu yang dilakukan NET TV untuk program Customs Protection ini tentunya yang menarik menurut tim NET TV dan isu yang tetap menjaga nama baik Dirjen Bea Cukai untuk ditayangkan. Sedangkan penonjolan isu yang dilakukan selain menempatkan isu penyelundupan narkoba menjadi segmen utama, NET TV juga melakukan penonjolan melalui editting serta testimoni yang dilakukan oleh narasumber.

Dalam melakukan penyeleksian isu dan penonjolan aspek tentu saja NET TV mempunyai kebijakan yang telah disepakati bersama termasuk dengan Dirjen Bea Cukai. Menurut Yudhistira selaku Asisten Produksi Customs Protection, NET TV akan menayangkan materi yang sekiranya tidak menjatuhkan nama baik Dirjen Bea Cukai dan menayangkan realita positif yang akan membuat efek positif bagi segala pihak yaitu NET TV, penonton, dan pihak Bea Cukai itu sendiri. NET TV tidak akan menayangkan materi yang terdapat oknum melakukan hal negatif dan dapat membuat nama baik Dirjen Bea Cukai menjadi jatuh dikarenakan sudah terdapat kerjasama antara Dirjen Bea Cukai dengan NET TV. ${ }^{11}$ Kerjasama yang dilakukan NET TV dengan Bea Cukai pun berbentuk, NET TV mendapatkan berita, aksi petugas, dan

\footnotetext{
${ }^{11}$ Hasil Wawancara dengan Yudhistira Utama selaku Production Assistant Customs Protection NET TV Pada 23 September 2016

${ }^{12}$ Hasil Wawancara dengan Wildan Kesuma Putra selaku Production Assistant Customs Protection NET TV Pada 23 September 2016
}

mendapakan cerita sedangkan untuk Dirjen Bea Cukai mendapatkan nama baik melalui tayangan Customs Protection ini. ${ }^{12}$ Sedangkan dalam penekanan aspek, NET TV melakukan editting yang dilakukan oleh editor NET TV. Jika terdapat aspek tertentu yang ingin disampaikan seperti dalam episode "Penelusuran Sabu Cair". Dalam episode ini, NET TV ingin menekankan bahwa petugas baru pertama kali menemukan modus ini di kantornya. Maka editor akan memberikan efek suara menegangkan disertai dengan efek gambar hitam putih atau transisi untuk lebih menegaskan bahwa modus tersebut adalah modus baru.

Menurut Devid Yohannes Muhammad selaku Kasie Hubungan Masyarakat Dirjen Bea Cukai, pihak Bea Cukai sudah cukup merasakan nama baik dan penyemapaian informasi yang tidak dapat dilakukan oleh pihak Bea Cukai tetapi sudah tersampaikan melalui Customs Protection. Hal tersebut sangat menguntungkan pihak Bea Cukai dengan adanya kerjasama antara NET TV dengan Bea Cukai. Menurutnya dahulu masih belum banyak yang mengetahui petugas Bea Cukai yang mampu menangkap penyelundup narkoba karena masyarakat pikir hanya polisi yang dapat menangkap. Tetapi dengan adanya Customs Protection lambat laun masyarakat mulai mengetahui hal tersebut. Beberapa kebijakan kepabeanan dan cukai pun mulai dimengerti masyarakat yang ingin keluar negeri dengan adanya Customs Protection ini. ${ }^{13}$

Pihak Dirjen Bea Cukai berharap dari tayangan khusus penyelundupan narkoba ini, NET TV dapat menghantarkan citra pelayanan dan perlindungan terhadap masyarakat yang dilakukan petugas pelayanan di berbagai kantor Bea Cukai daerah. ${ }^{14}$ Pada beberapa episode yang telah ditayangkan NET TV, terlihat dalam Customs Protection petugas sudah melakukan

\footnotetext{
${ }^{13}$ Hasil Wawancara dengan Devid Yohannes Muhammad selaku Kasie Hubungan Masyarakat Dirjen Bea dan Cukai Kementerian Keuangan RI Pada 9 September 2016

${ }^{14}$ Hasil Wawancara dengan Devid Yohannes Muhammad selaku Kasie Hubungan Masyarakat Dirjen Bea dan Cukai Kementerian Keuangan RI Pada 9 September 2016
} 
adegan-adegan yang berusaha mengantarkan citra pelayanan dan perlindungan. Kemudian NET TV melakukan penegasan dalam bentuk testimoni oleh narasumber yang sudah dipilih disertai dengan efek suara dan efek gambar yang sesuai. Dengan pembingkaian yang dilakukan oleh NET TV melalui tayangan khusus penyelundupan narkoba, dengan melakukan penyeleksian isu dan penonjolan aspek, hal tersebut dapat menggiring opini publik tentang citra dan reputasi Dirjen Bea Cukai.

\section{SIMPULAN}

1. NET TV membingkai kasus penyelundupan narkoba dengan menampilkan empat pendefinisian masalah, empat perkiraan penyebab masalah, empat keputusan moral, dan empat penekanan penyelesaian masalah. Dengan melakukan penyeleksian isu bersama kesepakatan pihak Dirjen Bea dan Cukai serta melakukan penonjolan isu melalui editing, teks secara lisan maupun tulisan, serta gestur pemain.

2. NET TV membingkai citra Dirjen Bea Cukai menjadi citra pelayanan yang terdiri dari profesional, serius, kerja keras, dan citra perlindungan yang terdiri dari tegas dan cerdik.

\section{SARAN}

1. Pendefinisian masalah yang diperlihatkan kepada publik dapat menjadi bahan evaluasi Dirjen Bea Cukai untuk meningkatkan koordinasinya dengan pihak terkait dan meningkatkan Sumber Daya Manusia di dalamnya, agar tidak menjadi celah bagi penonton untuk mencela Dirjen Bea Cukai.

2. Jika terdapat episode rekonstruksi, NET TV sebaiknya mencantumkan bahwa episode tersebut adalah rekonstruksi agar tidak ada lagi masyarakat yang menganggap program ini adalah setting-an.
3. Sebaiknya NET TV sebagai media massa lebih objektif dan berimbang dalam menayangkan informasi kepada publik serta tidak hanya mengutamakan rating semata, tetapi kualitas tayangan yang dihadirkan kepada publik.

4. NET TV menghadirkan pula tayangan wawancara dari sisi pelaku untuk menghadirkan tayangan yang lebih berimbang dan mecegah terdapat pelakupelaku lainnya.

5. Litimasi dalam penelitian ini ialah sifatnya yang terbatas pada analisis teks media saja, tanpa mengkritisi lebih dalam faktor lain terkait di dalam media yang mempengaruhi agenda pemberitaan media. Peneliti mengharapkan pada penelitian selanjutnya dapat menitikberatkan pada seluruh komponen framing, bukan hanya pada teks saja. Hal ini bertujuan memberikan temuantemuan baru terkait penggunaan subjek dan objek penelitian.

\section{DAFTAR PUSTAKA}

Elviano Ardianto, Lukiati Komala, Siti Karlinah. 2007. Komunikasi Massa. Bandung: Simbiosa Rekatama Media.

Bungin, Burhan. 1990. Konstruksi Sosial Media Massa: Kekuatan Pengaruh Media massa, Iklan Televisi dan Keputusan Konsumen serta Kritik Terhadap Peter L. Berger \& Thomas Luckman. Jakarta. Kencana Prenada Media Group.

Entman, Robert. 2004. Project of Power: Framing News, Public Opinion, and U.S. Foreign Policy. Chicago. The University of Chicago Press.

Eriyanto.2002. Analisis Framing. Yogyakarta : LkiS Yogyakarta.

Morissan, Andy Corry Wardhani, Farid Hamid. Teori Komunikasi Massa. Bogor: Ghalia Indonesia 